\title{
Synod dla Azji w świetle polskiej prasy katolickiej
}

\author{
Synod for Asia in the light of the Polish Catholic press
}

Od Nowosybirska po Dżakartę, od Tokio po Bejrut, Azja budzi zachwyt i zdumienie. Tu właśnie ogniskują się rozmaite sprzeczności: stare tradycje religijne i społeczeństwo przyszłości, najbardziej dynamiczne tygrysy światowego kapitalizmu obok pozostałości ustroju komunistycznego. Azja jest także kolebką wielkich światowych religii. Na tym kontynencie powstał hinduizm, buddyzm, islam, judaizm oraz chrześcijaństwo. Tu także rozpoczęła się misja głoszenia Dobrej Nowiny przekazanej uczniom przez Jezusa Chrystusa.

Pierwsze tysiąclecie otworzyło serca ludności europejskiej, drugie zaś było świadkiem misji w Afryce i obu Amerykach. Jan Paweł II pragnął, by w dziejach zbawienia ludzkości, u progu trzeciego tysiąclecia wybiła wreszcie godzina dla Azji, do czego impulsem miało być zwołanie Specjalnego Zgromadzenia Biskupów dla owego kontynentu. Myślą przewodnią synodu stało się hasło: „Jezus Chrystus - Zbawiciel oraz Jego misja służby i miłości w Azji”. W poniższym artykule prześledzimy jak owe zgromadzenie zostało ukazane na łamach czołowych polskich czasopism katolickich, mających największy wpływ na świadomość religijną i misyjną.

\section{PRZEBIEG SYNODU}

Jan Paweł II wyraził potrzebę zwołania specjalnych synodów kontynentalnych w liście apostolskim „Tertio Millennio Adveniente” - będącym preludium do obchodów Jubileuszowego Roku 2000. Zgromadzenia biskupów wyrastały z soborowej wizji Kościoła, otwierającej szeroką perspektywę dla wszystkich wierzących. Przed specjalnym synodem dla krajów azjatyckich, odbyły się już pierwsze spotkania biskupów z Europy, Afryki oraz Ameryki Północnej i Połu- 
dniowej. O zapowiedziach zwołania synodu dla kontynentu azjatyckiego mogliśmy dowiedzieć się z polskiego wydania „L'Osservatore Romano”, „Przeglądu Powszechnego” oraz „Misyjnych Dróg”.

Papież podjął prace przygotowawcze na spotkaniu z przedstawicielami Federacji Konferencji Episkopatów Azji. Wydarzenie to miało miejsce 15 stycznia 1995 r. w Manili. Podczas wizyty Jan Paweł II zwrócił się o pomoc w zorganizowaniu synodu poświęconego Azji oraz zaapelował do hierarchów o sporządzenie dokumentu roboczego.

Pozytywna odpowiedź reprezentantów episkopatu zaowocowała powołaniem we wrześniu 1995 r. piętnastu członków Rady Sekretariatu Synodu Biskupów, ta data wyznacza również początek pracy według określonego wcześniej regulaminu. Wydarzenie w Manili znalazło odzwierciedlenie w „Idźcie na cały świat” oraz w „Misyjnych Drogach”, które dodatkowo poinformowały o powołaniu członków Rady Synodu. O spotkaniu papieża z biskupami w stolicy Filipin pisało także polskie wydanie „L'Osservatore Romano” nakreślając główny temat i charakter spotkania.

Pierwszym etapem pracy hierarchów było opracowanie dokumentu wstępnego nazywanego „Lineamenta”. W związku z jego przygotowaniem Rada Sekretariatu wysłała we wrześniu 1996 r. specjalnie zredagowany kwestionariusz złożony z jedenastu pytań, na które odpowiedziało zarówno wielu biskupów jak i teologów.

Nie możemy pominąc tu pewnej krytyki jaka została skierowana w stosunku do „Lineamenta”. Pojawiły się uwagi ze strony Kościoła japońskiego, odnoszące się do jego metodologii. Hierarchowie podkreślili konieczność thumaczenia dokumentów przygotowawczych na język japoński i potrzebę dodatkowego czasu, by mogli je poddać pod dyskusję. Konferencja Episkopatu Japonii uznała pytania zawarte w „Lineamenta” za zbyt europejskie. Perspektywa spojrzenia zachodniego nie uwzględniła w swoim polu widzenia duchowego poziomu ludności azjatyckiej. Zwrócono także uwagę na fakt, iż to nie rzymskie sekretariaty mają podawać tematykę synodu, ale biskupi azjatyccy powinni mieć tu pierwszeństwo. Zaapelowano również, by wśród obserwatorów biorących udział w zgromadzeniu nie zabrakło przedstawicieli płci żeńskiej. Przez ten fakt chciano przełamać i przekreślić dość powszechną dyskryminację kobiet jaka obecna jest na terenie Azji. Biskupi japońscy opracowali swój kwestionariusz na podstawie nadesłanych z całego kraju propozycji. Zaakcentowali inne kwestie, jednak pozostali wierni duchowi głównego tematu. Misyjne czasopismo „Nurt SVD” dostrzegło odpowiedź biskupów z Kraju Wiśni i zatroszczyło się o przekład oficjalnej odpowiedzi episkopatu tego kraju.

O „Lineamenta” wypowiedzieli się także hierarchowie z Filipin, którzy podkreślili, iż zgromadzenie biskupów w Watykanie powinno być prawdziwie azjatyckie oraz obejmować owoce wypracowane przez FABC. Zaznaczyli także spe- 
cyficzną duchowość kontynentu oraz perspektywę jaką niesie ze sobą rozwój teologii azjatyckiej. Z kolei biskupi indyjscy położyli nacisk na brak troski o elementy odnoszące się do mistyki i duchowości w Azji, co mogło stanowić istotną przyczynę niepowodzeń misji.

Episkopat Wietnamu dostrzegł natomiast, iż nadmierną uwagę przywiązuje się do prawowierności Kościoła azjatyckiego. Mozaika religijna i kulturowa widziana oczami zachodu nie może usilnie dopatrywać się potencjalnych zagrożeń i odstępstw. Hierarchowie zwrócili szczególną uwagę na potrzebę inkulturacji. Informacje odnoszące się do utworzenia wspomnianego dokumentu polscy czytelnicy mogli uzyskać podczas lektury „Misyjnych Dróg” oraz polskiego wydania „L'Osservatore Romano”.

Kolejnym krokiem było opracowanie kwestionariuszy oraz opinii biskupów jakie zostały nadesłane do Stolicy Apostolskiej, by stworzyć dokument roboczy - „Instrumentum Laboris”. Po wytężonych pracach opublikowano go w lutym 1998 r., w języku angielskim i francuskim. Dokument nawiązywał do głównego tematu, jaki został określony dla synodu: „Jezus Chrystus Zbawiciel oraz Jego misja miłości i służby w Azji”. Tak sformułowana myśl zamierzała ująć unikalny problem okoliczności, w jakich znajduje się Kościół w Azji oraz zając się faktycznym stanem mieszkających tam wiernych. Istotne było podkreślenie, zgodnie z ideą hasła przewodniego, osoby Jezusa Chrystusa jako jedynego Zbawiciela. W samym dokumencie wyróżniono siedem rozdziałów wraz ze słowem wstępnym i zakończeniem. Krótkie omówienie poszczególnych rozdziałów, jakie zawierało „Instrumentum Laboris” mogliśmy znaleźć na łamach polskiego wydania „L'Osservatore Romano”. Natomiast niewielkie wzmianki mówiące o utworzeniu wspomnianego dokumentu znalazły się w „Gościu Niedzielnym” oraz „Misyjnych Drogach”.

Na kanwie „Lineamenta” oraz „Instrumentum Laboris” stworzono punkt wyjścia dla dyskusji synodalnej. Wypowiedzi ojców synodalnych podawane były w ukazującym się codziennie biuletynie prasowym poświęconym owemu zgromadzeniu. Natomiast wszyscy zainteresowani mogli takie informacje odszukać na łamach włoskiej wersji „L'Osservatore Romano”, lub na oficjalnych stronach internetowych Watykanu.

Inauguracja obrad Specjalnego Zgromadzenia Synodu Biskupów dla Azji nastapiła w Bazylice św. Piotra w Watykanie dnia 19 kwietnia 1998 roku. Ceremonii rozpoczęcia towarzyszyły obrzędy i muzyka wywodząca się z azjatyckiej kultury, jak donosił „Biuletyn KAI”, na którego łamach czytamy, iż „dary ołtarza przynieśli indonezyjscy tancerze w strojach ludowych podczas innych części liturgii wykonywano muzykę wywodząca się z Indii i Korei”'. Mury Bazyliki Watykańskiej usłyszały niejako nową pieśń azjatyckich instrumentów oraz mo-

\footnotetext{
${ }^{1}$ Zgromadzenie Specjalne Synodu Biskupów dla Azji, „Biuletyn KAI” (1998) nr 16, s. 3.
} 
dlitwę wiernych w rodzimych językach Azji, co zaakcentowano w artykule napisanym dla „Misyjnych Dróg”.

Kardynałowie, arcybiskupi, biskupi i księża pochodzący z kontynentu azjatyckiego sprawowali Eucharystię wspólnie z Ojcem Świętym. Znamienne były fragmenty Pisma Świętego czytane podczas liturgii, o czym mogliśmy dowiedzieć się z lektury „Gościa Niedzielnego” gdzie opisano nawiązania papieża do czytań przypominających wydarzenia $\mathrm{z}$ wieczernika tydzień po Zmartwychwstaniu Pana. Wśród zgromadzonych uczniów, obecny był niedowierzający św. Tomasz, który umocnił wiarę w spotkaniu ze Zmartwychwstałym, by następnie przynieść Dobrą Nowinę na teren Indii.

Jan Paweł II uwypuklił fakt, że to właśnie Azja jest kolebką naszej wiary, co zostało podkreślone na łamach „Biuletynu KAI”. Papież zaakcentował także, że synod powinien wsłuchać się w przekaz Ducha Świętego, by nie tylko wiedzieć, ale i zrozumieć, jak powinien być głoszony Jezus Chrystus w kontekście innych religii. Zaakcentowano także potrzebę dawania świadectwa życia i nowej aktywności misyjnej co zostało zawarte W „Misyjnych Drogach” oraz „Biuletynie KAI".

Na uwagę zasługuje także zainteresowanie papieża nieobecnością biskupów z Chin, którzy z powodów politycznych nie otrzymali zgody na opuszczenie kraju. Brak biskupów z Państwa Środka został szeroko podjęty na łamach „Gościa Niedzielnego”, „Biuletynu KAI” oraz „Niedzieli” i „Przeglądu Powszechnego”. W przekazach prasy zawarto informację, iż hierarchowie nie przybędą do Watykanu ze względu na brak wiz oraz pokrótce nakreślono jak wygląda obecna sytuacja Kościoła w tym kraju. Hierarchowie chińscy wystosowali w trakcie trwania synodu faks zredagowany w języku łacińskim, w którym zawarli głębokie ubolewanie, iż nie mogą uczestniczyć w obradach, o czym poinformowano czytelnika w polskim wydaniu „L'Osservatore Romano”. Krótkie informacje o telegramie znalazły się na łamach „Niedzieli”, „Biuletynu KAI” oraz „Misjonarza”. Prasa zaakcentowała więc nie tylko sam fakt nieobecności hierarchów ale śledziła dalsze wydarzenia związane z zaistniałą sytuacją.

Po rozpoczęciu zgromadzenia uroczystą Eucharystią, podjęto obrady. W pracach synodu uczestniczyli głównie biskupi, ale nie zabrakło także ekspertów, audytorów oraz delegatów przybyłych z innych Kościołów chrześcijańskich. Łącznie w Watykanie zgromadziło się ponad trzysta pięćdziesiąt osób. O liczbie uczestników synodu pisała na swoich łamach „Niedziela”, „Biuletyn KAI”, „Gość Niedzielny”, „Idźcie na cały świat”, „Misyjne Drogi” oraz polskie wydanie „L'Osservatore Romano”. Na synodzie nie zabrakło także Polaków. Wśród ojców synodalnych obecny był administrator apostolski Kazachstanu - biskup Jan Paweł Lenga a także dwaj przełożeni misji kościelnych sui iuris podlegających bezpośrednio Watykanowi, ojciec Krzysztof Kukułka z Uzbekistanu oraz ojciec Andrzej Madej z Turkmenistanu. Obecność Polaków na synodzie została 
podkreślona jedynie na łamach polskiego wydania „L'Osservatore Romano” oraz „Misyjnych Dróg”.

Przewodnictwo Synodu zostało powierzone prefektowi kongregacji do spraw Ewangelizacji Narodów - Józefowi Tomko, Juliusowi Riyadi Darmaatmadaja oraz Stephanowi Kim Sou-hwanowi. Relatorem generalnym mianowano kardynała Paula Shan Kuo-hsi, o czym mogliśmy dowiedzieć się z polskiego wydania „L'Osservatore Romano” oraz czasopisma „Misyjne Drogi”.

Dzień po uroczystej ceremonii rozpoczęto dwutygodniowe prace nad pierwszą fazą obrad zogniskowaną w trzynastu kongregacjach. Zarysowano najważniejsze etapy oraz rozpoczęto dyskusję nad obecną sytuacją panującą w Kościele azjatyckim. Dyskutowano także o problemach religijnych, społecznych, ekonomicznych i politycznych.

Ojcowie Synodalni nie pozostali tylko w ciemnym kręgu problemów Azji. Uwypuklono wiele pozytywnych znaków nadziei, które koncentrowały się wokół swoistego głodu wartości wyższych i duchowych, jakie daje się zauważyć wśród ludności azjatyckiej.

Synteza dyskusji znalazła odzwierciedlenie w dokumencie o nazwie „Relatio post disceptationem", o czym czytelnicy mogli dowiedzieć się z lektury polskiego wydania „L'Osservatore Romano”. W pierwszym polu omawianych zagadnień znalazły się tematy chrystologiczne, pneumatologiczne i eklezjologiczne, nie zabrakło również problematyki wielokulturowości i wielo-religijności kontynentu azjatyckiego. Kolejny krąg objął sprawy dotyczące ewangelizacji, dialogu między religiami, liturgii oraz tematy poświęcone rodzinie, godności kobiety, wychowaniu, ochronie zdrowia czy sprawiedliwości społecznej.

Kolejna faza obrad - druga oraz trzecia - przybrała charakter bardziej analityczny. W tym czasie odbywały się spotkania i dyskusje w małych grupach językowych. W ten sposób zdołano wyodrębnić jedenaście zespołów roboczych podzielonych na poszczególne języki. Po zakończonych dyskusjach w poszczególnych grupach, moderator przedstawił na auli rezultaty prac. O przebiegu poszczególnych faz obrad, mogliśmy dowiedzieć się w krótkiej recenzji zawartej w czasopiśmie „Misyjne Drogi” oraz w szerszym opracowaniu, jakie przedstawiło polskie wydanie „L'Osservatore Romano”.

Na podstawie analizy tychże wyników, ojcowie synodalni opracowali tzw. „Propositiones”, stanowiące podstawę do stworzenia wniosków końcowych obrad. Sam tekst owego dokumentu nie został podany do publikacji, wiemy jedynie, że został on przekazany 13 maja na ręce Ojca Świętego, by mógł on wspierać się na jego przesłaniach podczas tworzenia posynodalnej adhortacji. Informacje o „Propositiones” zamieszczono w „L'Osservatore Romano”, „Misjach Dzisiaj” oraz „Gościu Niedzielnym”.

Prace synodu zaczęły powoli dobiegać końca. Na jednym z końcowych ze- 
brań kongregacji generalnej podjęto głosowanie tajne, którego celem było wyłonienie członków Posynodalnej Rady Sekretariatu Generalnego Synodu, których poznaliśmy dzięki polskiemu wydaniu „L'Osservatore Romano”. Organ ten będzie wspomagał hierarchów kontynentu azjatyckiego we wprowadzaniu w życie postanowień synodu, jakie będą zawarte w posynodalnej adhortacji „Ecclesia in Asia”.

W przeddzień zakończenia zgromadzenia zostało ogłoszone specjalne orędzie skierowane do Ludu Bożego, z którego treścią mogliśmy zapoznać się w polskim wydaniu „L'Osservatore Romano”. Omówienie orędzia znalazło się w „Misyjnych Drogach", gdzie streszczono najważniejsze wnioski podjęte przez biskupów oraz w „Misjach Dzisiaj” w których omówiono najważniejsze punkty przemówienia. Przesłanie biskupów zostało również ukazane w „Niedzieli” oraz „Gościu Niedzielnym”, gdzie mogliśmy zapoznać się z jego głównymi konkluzjami. Ostatnim aktem wieńczącym obrady synodu była Msza Święta koncelebrowana w Bazylice Watykańskiej 14 maja 1998 r. Mimo, iż Eucharystia była sprawowana według rytu łacińskiego, nie zabrakło w niej elementów pochodzących z tradycji azjatyckiej. Jan Paweł II poinformował także zgromadzonych, że pragnąłby odbyć podróż apostolską do Azji, by na jej terenie przekazać wiernym owoc obrad, czyli posynodalną adhortację „Ecclesia in Asia”. Złożenie na ich ręce owocu wytężonej pracy ich przedstawicieli stanowi swoiste dowartościowanie oraz wyraz pełnej troski o ich wzrost w wierze.

\section{PROBLEMATYKA SYNODU}

Biskupi zgromadzeni w Watykanie podczas obrad pragnęli ukazać prawdziwe oblicze Kościoła azjatyckiego, który nie jest pozbawiony trudnych i bolesnych spraw. Podczas lektury polskiej prasy katolickiej mogliśmy zapoznać się z palącymi problemami owego kontynentu. W pierwszej kolejności przedstawimy kwestie obejmujące sprawy z zakresu życia społecznego, ekonomicznego i politycznego. Wypowiedzi biskupów zostały zaczerpnięte z polskiego wydania „L'Osservatore Romano”, które podało thumaczenia wystapień.

Hierarchowie zwrócili uwagę na panujący wyzysk krajów biednych przez kraje wysoko uprzemysłowione oraz na nadmierną globalizację zmierzającą do nadmiernej liberalizacji i prywatyzacji, co skutkuje niszczącymi skutkami dla środowiska naturalnego. Arcybiskup D’Souza zaproponował, by budować cywilizację miłości, wzywającej do spojrzenia na świat w perspektywie chrześcijańskiej. W związku z taką wizją należałoby kontrolować systemy handlu w sposób mogący zapewnić opiekę najsłabszym, którzy potrzebują pomocy z zewnątrz by obronić się przed wyzyskiem. Ponadto istotną sprawą było położenie nacisku na pierwszeństwo człowieka w dziedzinie zarówno finansów jak i przemysłu. 
Problemy ekonomiczne nie mogły być oddzielone od spraw społecznych, gdyż obie te sfery wzajemnie łączą się i przenikają. Palącą kwestią stało się ubóstwo, niedożywienie oraz rodzące się konflikty społeczne. Kardynał Kim Souhwan w przemówieniu cytowanym przez „Niedzielę” i „Gościa Niedzielnego” wspomniał o śmiercionośnych siłach zagrażających kulturze życia i wspólnoty, które przejawiają się w coraz powszechniejszym materializmie i zobojętnieniu na życie duchowe. Kardynał zaakcentował także szerzący się relatywizm i konsumpcjonizm prowadzący do osamotnienia i wyizolowania człowieka. W środowiskach gdzie liczą się jedynie osobiste zyski, coraz mniej miejsca zostaje dla bliźniego potrzebującego wsparcia i opieki.

O aspektach nierówności i niesprawiedliwości nie zawahał się mówić kardynał Kim Sou-hwan, zaznaczając tym samym fakt, iż Kościół nie może pozostać obojętny wobec wspomnianych przez niego kwestii i powinien aktywnie angażować się w najważniejsze sprawy dotykające bezpośrednio wiernych. Znamienitym przesłaniem hierarchy były słowa mające na celu wyzbycie się poczucia bezpieczeństwa, gdyż nie raz głosząc orędzie Jezusa Chrystusa wierni spotkają się nie tylko z niezrozumieniem ale również z oporem wobec działań wymierzonych przeciwko szerzącej się kulturze śmierci.

Głos arcybiskupa Barragana poruszył sprawę opieki zdrowotnej. Według hierarchy troska o zdrowie powinna stanowić płaszczyznę współpracy nie tylko dla chrześcijan, ale również innych religii działających na jej rzecz. W założeniach Barragana nie dominował jedynie aspekt czysto medyczny, dążący jedynie do upowszechnienia i humanizacji leczenia. W jego wypowiedzi obecna była myśl, iż istotne jest ukazanie przy tej tematyce godności człowieka i świętości jego życia. Dziedzina opieki zdrowotnej ma także szansę podnieść rolę kobiet, o czym mówił biskup Soreng. Dziewczęta służąc jako pielęgniarki w prywatnych klinikach i domach opieki stają się świadkami Jezusa poprzez służbę drugiemu człowiekowi. Synod poświęcił sporo uwagi trudnej sytuacji niewiast w społeczeństwie azjatyckim, o czym polski czytelnik mógł dowiedzieć się z lektury „Niedzieli” oraz „Idźcie na cały świat”.

Przemiany dokonujące się $\mathrm{w}$ gospodarkach niejednokrotnie niosą za sobą zaburzenia nie tylko na tle społecznym, ale również politycznym, gdyż władze chcąc zapewnić sobie potencjalny zysk z przemian ekonomicznych kierują się interesem nie narodu, lecz własnym.

Biskupi obradujący na synodzie nie ominęli tego obszaru gdyż w niejednym kraju azjatyckim obecny jest ustrój komunistyczny ograniczający wolność religijną mieszkańców. O potrzebie pomocy dla Kościoła, dotkniętego represjami władz wypowiadał się biskup John Tong Hon mówiący o sytuacji panującej w Chinach. Hierarcha zaznaczył, iż władze są zainteresowane przede wszystkim możliwością kontrolowania wszelkich dziedzin życia, w tym także religii. Podczas prowadzenia polityki ścisłej kontroli pogłębiał się rozłam pomiędzy wspól- 
notami kościelnymi, które w sposób jawny sprawowały kult, a tymi pozostającymi w ukryciu.

O obronie wolności religijnej w Chinach wypowiedział się biskup Andrew Tsien Chih-ch'un, który również wspomniał o prześladowaniach, jakich doświadczają wierni należący do Kościoła podziemnego, nazywając go Kościołem lojalnym wobec następcy św. Piotra. Pragnął w swoim wystąpieniu zaznaczyć, iż potrzebna jest solidarność z cierpiącymi za wiarę i poparcie ze strony Stolicy Apostolskiej dla biskupów i wierzących wiernych papieżowi. Bolesny rozłam Kościoła na terenie Chin stanowi nie lada problem dla Kościoła powszechnego, gdyż działania jednoczące są hamowane przez ustrój komunistyczny. Jednak mimo wielu problemów jakie napotykają wierni chińscy nie brakuje w tym kraju pozytywnych ziaren nadziei wspomnianych przez biskupa Tong Hona mówiącego o mężnych świadectwach wiary ludzi represjonowanych ze względu na przynależność do Kościoła katolickiego. Hierarcha dostrzegł ciagle kwitnące powołania zakonne stanowiące szansę na przetrwanie trudnego okresu. Oprócz wypowiedzi hierarchy Tong Chona i Tsien Chih-ch'una jaką podało polskie wydanie „L'Osservatore Romano” mogliśmy zapoznać się z fragmentem wystapieniem biskupa Josepha Zen Zu-Kiuna zamieszczonego w tygodniku „Niedziela”. Koadiutor diecezji Hongkongu mówił o sytuacji wiernych w Chinach oraz o trudnym i bolesnym rozłamie na kościół podziemny i patriotyczny.

W szeregu krajów azjatyckich borykających się z problemami, jakie stawia religii ustrój socjalistyczny staje obok Chin - Laos, gdzie wraz z wprowadzeniem nowego ładu politycznego musieli opuścić kraj wszyscy misjonarze, co w konsekwencji spowodowało, iż wierni zamieszkujący kraj pozostali bez duszpasterzy. O tych skutkach mówił na synodzie wikariusz apostolski, biskup Jean Sommeng Vorachak.

Ustrój komunistyczny zagościł także w Korei Północnej, o której mówił metropolita Seulu, kardynał Stephen Kim Sou-hwan. Władze owego państwa w latach pięćdziesiątych starły wszelkie przejawy katolickości. Mimo iż, w kolejnych dziesięcioleciach państwo utworzyło Koreańskie Stowarzyszenie Katolickie oraz wzniosło w Phenianie katolicki kościół, działalność chrześcijan jest ograniczona i poddana kontroli państwa. Ścisły nadzór władz nad sferą religijną prowadzi niejednokrotnie do represji, co nie może pozostawać bez uwagi dla Kościoła powszechnego, który powinien wyrazić solidarność z prześladowanymi, o co apelował administrator apostolski Syberii, biskup Joseph Werth. Hierarcha dostrzegł, jak wielką wagę ma wsparcie z zewnątrz, gdyż takiego stanu rzeczy doświadczył Kościół działający w krajach byłego Związku Radzieckiego.

Ukazane w poprzednim podrozdziale zagadnienia z zakresu życia społecznego, ekonomicznego oraz politycznego stanowiły ważny element rozważań ojców synodalnych. Jednak zasadnicze miejsce podczas obrad zajęły zagadnienia odnoszące się do spraw Kościoła, misji oraz dialogu. Hierarchowie podejmując 
liczne dyskusje dzielili się swoimi doświadczeniami, zamierzeniami a także planami. W wystapieniach biskupów dominowały problemy i tematy specyficzne dla Kościołów lokalnych, ale nie zabrakło wśród nich zagadnień posiadających zasięg globalny, wypływających ze specyfiki oraz mentalności narodów azjatyckich oraz różnorodności religijnej.

Prowadzenie dialogu z innymi religiami i kulturami wymaga odpowiedniej formacji świeckich oraz duchownych. Ordynariusz z Filipin, biskup Arturo Bastes w swoim przemówieniu podkreślił istotę dostosowania formacji kandydatów do życia zakonnego do warunków lokalnych. Kościół w Azji nosi znamiona zbyt europejskie i wymaga przekształcenia się w Kościół prawdziwie azjatycki, nie będący monokulturową kopią zachodu o czym pisała „Niedziela” wraz z „Biuletynem KAI”. Mimo wielu trudności, jakie napotyka chrześcijaństwo na owym kontynencie, rośnie liczba powołań, co daje jasny sygnał dla wprowadzenia zmian. O tej kwestii wypowiadał się także arcybiskup Peter Chung Hoan Ting. Hierarcha podkreślił, że przygotowanie kapłanów powinno uwzględniać kontekst lokalny a wykładowcy odbywać formację oraz specjalistyczne studia w Azji. Kształtowanie kapłanów powinno być wrażliwe na tradycje religijne Azji, by w przyszłej pracy nie dochodziło do konfliktów i nieporozumień między wyznawcami oraz by pasterze potrafili umiejętnie prowadzić dialog $\mathrm{z}$ innymi, w duchu szacunku i miłości.

Formacja kapłanów i osób konsekrowanych powinna być połączona ze znajomością sytuacji społeczno-kulturowej oraz warunków ekonomicznych i politycznych. Kościół ma stać się kościołem identyfikującym się z ludźmi, którzy najczęściej są biedni. Biskup Bastes apelował, by kandydaci do życia zakonnego rzeczywiście angażowali się w pracę z ubogimi. Arcybiskup Chung Hoan Ting uzupełniał wspomnianą kwestię o potrzebę przestrzegania praw człowieka, które są nieustannie łamane w Azji.

Biskup Nicholas Cheong Jin-suk, mówił o potrzebie formacji i otoczenia troską duszpasterską rodzin, o czym mogliśmy przeczytać w „L'Osservatore Romano” i „Biuletynie KAI”. Hierarcha zwrócił uwagę, iż istotne jest podjęcie działań w tym zakresie, gdyż przyszła ewangelizacja w dużej mierze zależeć będzie od kościoła domowego. Kształtowanie i dbanie o rodzinę oraz formacja osób duchownych stanowią niejako dwa filary, na których podpierać się będzie rozwój chrześcijaństwa na kontynencie azjatyckim.

Na rozkwit wiary ma niewątpliwie wpływ także cały proces ewangelizacyjny, któremu poświęcono znaczną uwagę podczas obrad. W kontekście wielowiekowej pracy misyjnej i małej liczby katolików rodzi się pytanie jak należy głosić orędzie Jezusa Chrystusa by było ono zrozumiane i przyjmowane przez ludzi. Sprawa ta została poddana pod rozważania ojców synodalnych, i tak kardynał Stephan Kim Sou-hwan oraz biskup Augustinus Jun-ichi Nomura dostrzegli, iż niezwykle ważną rolę pełnić powinno osobiste świadectwo życia. Postępowanie 
chrześcijan jest najlepszym sprawdzianem wiary, dzięki niemu wierni dzielą się życiem danym przez Chrystusa z innymi. Świadectwo życia może przejawiać się w rozmiary sposób, chociażby poprzez ukazywanie godności osoby ludzkiej, o czym mówił metropolita Kalkuty, arcybiskup Henry Sebastian D’Souza. Jest to bardzo istotna kwestia, gdyż w wielu azjatyckich społeczeństwach dochodzi do poniżania człowieka i obdzierania go z jego podstawowych praw.

W obrębie świadectwa życia niezwykle ważną rolę sprawują kobiety, o których wspomnieliśmy wcześniej omawiając problemy społeczne, akcentując potrzebę podniesienia ich roli w społeczeństwie. Szansę na to daje praca wielu dziewcząt jako pielęgniarki, gdzie mają sposobność wykazania się troska, miłością i współczuciem wobec cierpiących i chorych. O ich zasługach mówił biskup Charles Soreng, wspominając również jakimi wspaniałymi świadkami Jezusa Chrystusa są kobiety pracujące wśród niechrześcijan. Hierarcha skierował także apel o to, by zatroszczyć się o formację religijną kobiet i mężczyzn by powierzyć im przygotowanie do pracy misjonarskiej, bowiem kościół w Azji nie może pozostawać ciagle w obszarze misyjnym. Ojciec Raymond Rossignol podkreślił wypowiedź biskupa Sorenga, mówiąc, że każdy Kościół partykularny powinien zarazem przyjmować i wysyłać misjonarzy.

Ojcowie synodalni podczas trwania obrad poruszyli także kwestię inkulturacji, o czym wspominano niejednokrotnie w polskiej prasie. W wielu wypowiedziach przewijały się spostrzeżenia na temat konieczności szacunku i rozeznania w stosunku do rzeczywistości azjatyckiej co zaakcentowano w „Gościu Niedzielnym” oraz w „Idźcie na cały świat”. Taka różnorodność kultur, tradycji i religii niewątpliwie wymaga troski i umiejętnego zaadoptowania do tradycji chrześcijańskiej tych aspektów, które są możliwe do przyjęcia. Niektórzy uczestnicy synodu wezwali Watykan do okazania większego zaufania lokalnym Kościołom w kwestiach tłumaczeń tekstów liturgicznych na miejscowe języki, o czym pisał „Biuletyn KAI” oraz „Przegląd Powszechny”.

O problemie inkulturacji mówił na synodzie, biskup Michael Bunluen Mansap, wspominając, iż dbanie o tą dziedzinę powinno rozciagać się na wszystkie płaszczyzny życia człowieka, by w duchu wolności nie budzić strachu poprzez pogróżki. Dostrzeganie pozytywnych aspektów kultury jest nieuniknione jeśli Kościół pragnie zakorzenić się w danym środowisku. Niezdolność do kompromisu działa niekorzystnie dla rozwoju wiary chrześcijańskiej. Jednym ze specyficznych elementów kultury Azji, o którym dyskutowano, był kult przodków praktykowany w wielu krajach. Biskup Tong Hon stwierdził, iż kult ten szeroko rozpowszechniony w Chinach oraz Wietnamie powinien być zaadoptowany przez Kościół. Sprawa poświęcona kultowi przodków przedstawiona została na łamach „Biuletynu KAI”, „Przeglądu Powszechnego” oraz w „Idźcie na cały świat”. We wspomnianej prasie znalazł się przekrój problemu wraz z cytatami zaczerpniętymi z wypowiedzi ojców synodalnych. 
Potrzeba pracy misyjnej i wiążąca się z nią inkulturacja jest niezwykle ważną sprawą dla kontynentu Azjatyckiego, jednak ojcowie synodalni nie pozostali obojętni wobec tych krajów, na terenie których potrzebne jest prowadzenie reewangelizacji. Ponowne krzewienie wiary należało rozpocząć na terenie państw byłego Związku Radzieckiego, o czym mówili przedstawiciele tamtejszych kościołów. Jako pierwszy zabrał głos przełożony misji sui iuris Turkmenistanu, ojciec Andrzej Madej, który podczas swojego wystappienia nakreślił sytuację Kościoła na terenie kraju. Niewątpliwie wieloletnia obecność reżimu sowieckiego destrukcyjnie wpłynęła na wiernych, jednak misjonarze przybywając do Turkmenistanu zdołali dotrzeć do niewielkiej grupy ludzi, którzy zachowali w pamięci swoje katolickie korzenie. Wierni przez lata pozbawieni opieki duszpasterskiej powinni być otoczeni szczególną troską i wsparciem, by wzmocnili swoją wiarę i odważnie głosili ją innym. Przełożony misji wymienił także pierwsze ziarna wiary, jakie udało się zasiać w Turkmenistanie, a należały do nich chociażby poszukanie katolickich rodzin, sprawowanie Eucharystii, organizowanie spotkań biblijnych czy otwarcie katechumenatu.

O podobnych kwestiach mówił także przełożony misji sui iuris Tadżykistanu, ksiądz Carlos Avila. Kapłan ten także zaakcentował potrzebę rozwijania zalaż̇ka chrześcijańskiego obecnego na tym terenie, a skutecznie thumionego przez dawny ustrój sowiecki. Obecna sytuacja i przychylne nastawienie władz pozwalają na odrodzenie się wrażliwości religijnej ułatwiającej podjęcie na nowo niełatwego dzieła ponownej ewangelizacji, w które wrysowane będzie poczucie łączności z kościołem powszechnym. Po wypowiedzi Avili zabrał głos przełożony misji sui iuris Uzbekistanu, ojciec Krzysztof Kukułka. Zakonnik ten, podobnie jak poprzednicy, opisał sytuację Kościoła katolickiego żyjącego w mniejszości. Wierni przez lata działający w ukryciu pragną wyjść z podziemia, ale jest to utrudnione ze względu na dominujący tam islam. Kapłani pracujący na tym terenie są wezwani do dawania bardziej czytelnego i przekonywującego świadectwa. Ojciec Kukułka wspomniał jak ważna jest działalność akcji charytatywnych. O tym aspekcie działania Kościoła mówił także administrator apostolski Kazachstanu, biskup Jan Paweł Lenga. Głoszenie Chrystusa wśród ludności wymęczonej trwającym reżimem sowieckim wymaga działania chociażby na polu ochrony zdrowia czy opieki nad ubogimi. Taki apostolat pozwala na dotarcie do wielu środowisk. Dla Kazachstanu otwiera się nowy rozdział tak jak przed Kościołem w Kirgistanie, o którego sytuacji mówił przełożony tego regionu będącego misją sui iuris, Alexander Kahn. Wyraził on wielką wdzięczność papieżowi za mianowanie nowych biskupów dla krajów po sowieckich i za utworzenie misji sui iuris. Wierni w Kirgistanie mimo, iż stanowią mniejszość, są bardzo aktywni nie tylko w parafiach ale również w swoich środowiskach świeckich. O chrześcijanach z byłego Imperium Sowieckiego jako jedyny pisał ojciec Cognasso w „Misyjnych Drogach" ukazując jak wierni, na nowo odkrywają samych siebie żyjąc w wolnym kraju. 
Wypowiedzi przełożonych misji sui iuris, obejmujących kraje byłego Związku Radzieckiego, są znakami wyznaczającymi kierunek i potrzebę podjęcia reewangelizacji. Azja jest więc kontynentem wymagającym szczególnej troski i wsparcia.

\section{POLSKA PRASA KATOLICKA O SYNODZIE}

Zwołanie Specjalnego Zgromadzenia Biskupów dla Azji było wydarzeniem wręcz przełomowym, co nie umknęło polskiej prasie katolickiej. Na łamach wielu pism mogliśmy zapoznać się nie tylko z informacjami napływającymi z Watykanu ale także z opracowaniami, komentarzami i felietonami odnoszącymi się do owego wydarzenia. Przyjrzyjmy się w pierwszej kolejności polskiemu wydaniu „L'Osservatore Romano”.

Na łamach czasopisma zostały zamieszczone homilie wygłoszone przez papieża na rozpoczęcie oraz zakończenie obrad, wypowiedzi biskupów na poszczególnych kongregacjach oraz orędzie ojców synodalnych skierowane do Ludu Bożego. Stanowiło to ogromny walor gdyż jedynie tu zamieszczono pełne wystapienia ojców synodalnych, które zostały podzielone według porządku poszczególnych kongregacji. Na łamach czasopisma brakowało jednak omówienia zamieszczonych wypowiedzi, chodź na pewne usprawiedliwienie można sobie pozwolić, gdyż zamieszczono jeden artykuł omawiający cały proces formowania zgromadzenia i przebiegu obrad. We wspomnianym tekście mogliśmy zapoznać się także z dwoma unikatowymi informacjami, które nie zostały zawarte w żadnym innym czasopiśmie. Pierwsza dotyczyła podania członków Posynodalnej Rady Sekretariatu Synodu, druga natomiast odnosiła się do przedstawienia darów jakie otrzymali uczestnicy zgromadzenia od samego papieża.

Omawiane czasopismo włączyło tylko jeden artykuł omawiający synod azjatycki, mimo to, czytelnik mógł po jego lekturze zarysować sobie ramy nie tylko obrad, ale również przygotowań jakie musiały je poprzedzić. Niewątpliwym brakiem było pominięcie w artykule Czesława Drężka, omówienia lub ukazania problemów jakie poruszone zostały na auli synodalnej. Jak już wspomnieliśmy, na uwagę zasługuje fakt, iż polskie wydanie „L'Osservatore Romano” jako jedyne podało pełne teksty wystapień hierarchów, co stanowiło jedno z głównych źródeł do opracowania artykułu. Stanowi to cenny walor, nawet jeśli czytelnicy mogli zapoznać się z przebiegiem synodu dopiero miesiąc po jego zakończeniu.

O synodzie pisał także „Biuletyn KAI”, który w sposób profesjonalny podaje mediom informacje o bieżącej działalności i stanowisku Kościoła. Na łamach pisma przedstawiono główną myśl jaką niosła ze sobą homilia na rozpoczęcie obrad. Podkreślono także akcenty wywodzące się z azjatyckiej kultury i tradycji, które zostały włączone w liturgię. Adnotacja ta zasługuje na wyszczególnienie gdyż w innych pismach nie było podobnej wzmianki. 
W relacji z synodu nie zabrakło informacji na temat liczby uczestników, na co poświęcono odrębną kolumnę. Pozostałe tytuły polskiej prasy katolickiej pomijały tę kwestię lub włączały ją w ogólne relacje. Biuletyn poruszył także problem nieobecności chińskich biskupów, którzy z przyczyn politycznych nie otrzymali zgody na wyjazd do Watykanu. Zagadnienia poruszane na auli synodalnej zostały potraktowane selektywnie. Krag zagadnień podanych w owym czasopiśmie zacieśnił się do kwestii religijnych. Jedynym poruszonym aspektem z zakresu życia społecznego była sprawa ubogich dzieci pozostających pod opieką Kościoła, wypowiedź ojca Wensa Padilli znalazła się jedynie na stronach KAI oraz „Niedzieli”. Drugie zaakcentowanie zagadnień społecznych można było odnaleźć w wypowiedzi kardynała Shan Kuo-Hsi, w której wymienione zostały problemy analfabetyzmu czy niewolniczej pracy najuboższych mieszkańców kontynentu. Ostatnia wzmianka odniosła się do sytuacji kobiet i rodziny, podczas krótkiej relacji zawierającej wypowiedź biskupa Nicholasa Cheong Jin-suka oraz siostry Filomeny Hirota i biskupa Remigiusa. To były jedyne punkty, w których dotknięto obszaru społecznego, zdecydowanie większą uwagę poświęcono problemom pozostającym w kręgu religijnym. Na dwadzieścia jeden wypowiedzi azjatyckich biskupów zawartych w biuletynie, aż szesnaście dotyczyło kwestii religijnych. Najwięcej głosów poświęcono sprawie inkulturacji². Na łamach czasopisma można było zapoznać się z pojedynczymi wypowiedziami biskupa Basters, dotycząca potrzeby azjatyckiego modelu ewangelizacji oraz kardynała Shan Kuo-hsi, który zwrócił uwagę na fakt iż, Azja jest kolebką wszystkich wielkich religii. Dwie wypowiedzi przypadły na podkreślenie wyjątkowości Jezusa Chrystusa jako jedynego Zbawiciela ${ }^{3}$. Pozostałe głosy odnosiły się do sytuacji w Kościele jerozolimskim i koreańskim, oraz do kwestii stosunków z islamem, mówiono także o potrzebie wykształcenia katolików ${ }^{4}$.

Niewątpliwie pozytywnym aspektem w przekazie informacji z synodu była bieżąca relacja, gdyż „Biuletyn KAI” jest pismem wydawanym raz w tygodniu. Czytelnik mógł więc śledzić postępy w pracach ojców synodalnych.

${ }^{2}$ W „Biuletynie KAI” zamieszono siedem wypowiedzi ojców synodalnych odnoszących się do problemu inkulturacji, były to głosy biskupa Francisco Clavera, biskupa Francisa Hadisumatra, biskupa Johna Tong Hona, biskupa Hguyen Son Lam, arcybiskupa Etienne Nguyen Nhu Thę, biskupa Teodora Bacani oraz biskupa Michaela Bunluena Mansapa.

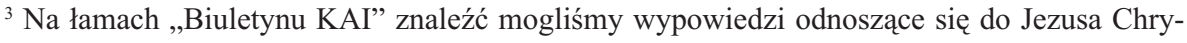
stusa jako jedynego Zbawiciela, autorstwa kardynała Williama Bauma oraz biskupa Alberta Ranjith Patabendige Dona.

${ }^{4}$ Odnośnie sytuacji jaka znajduje się na terenie Ziemi Świętej wypowiadał się arcybiskup Cyrille Salim Bustors oraz arcybiskup Michael Sabbah. Natomiast o uwarunkowaniach koreańskiego Kościoła mogliśmy dowiedzieć się z wystapienia kardynała Stephana Kim Sou-hwana. O sprawie stosunków z islamem zostały zamieszczone głosy biskupa Josepha Couttsa oraz biskupa Boutrosa Marayati, natomiast o potrzebie kształcenia i podnoszenia kwalifikacji katolików mogliśmy dowiedzieć się z wypowiedzi Josepha Pawathili. 
Zgromadzenie poświęcone Azji nie zostało pominięte przez ogólnopolskie czasopisma katolickie. „Gość Niedzielny” umieścił na swoich łamach wzmiankę o przygotowaniu „Instrumentum Laboris” - dokumentu będącego podsumowaniem odpowiedzi hierarchów na „Lineamenta”. Zwrócono także uwagę na spotkanie hierarchów w Quezon City na Filipinach podczas którego dyskutowano o problemach religijnych i ekonomicznych. Biskupi zwrócili uwagę na wady strukturalne gospodarki i na coraz powszechniejszy wyzysk biednych. Po ukazaniu elementów przygotowawczych rozpoczęto relacje z uroczystej inauguracji obrad. Czytelnik mógł zapoznać się z główną myślą wyrażoną przez papieża w homilii. W dalszej części zawarto informacje o liczbie uczestników oraz zaakcentowano fakt nieobecności biskupów z Chin.

Problemy poruszane na synodzie były ukazane w „Gościu Niedzielnym” dość selektywnie. W czasopiśmie ukazano jedynie dwa zagadnienia, stanowiące najistotniejsze punkty. Na łamach czasopisma pojawiła się tylko jedna wypowiedź kardynała Kuo-hsi, odnosząca się do sprawy analfabetyzmu i wyzysku biednych oraz zdawkowe przesłanie o potrzebie podjęcia inkulturacji. Mimo ubogiego ukazania problematyki obrad, w kolejnym numerze mogliśmy zapoznać się z omówionym szerzej orędziem jakie wystosowali do Ludu Bożego ojcowie synodalni.

Przedstawione powyżej informacje ukazywały czytelnikowi główny zarys synodu poświęconego Azji. Jest to niewatpliwie pozytywny aspekt, jednak w przekazie zawartym w czasopiśmie brakuje do ukazania całości, krótkiego omówienia homilii na zamknięcie obrad.

Kolejnym tygodnikiem w którym odnaleźliśmy wzmianki na temat synodu jest „Niedziela”. W piśmie zamieszczono pierwszą skrótową informację o zgromadzeniu w dwa tygodnie po jego rozpoczęciu, odnosiła się ona do homilii wygłoszonej przez Jana Pawła II. Podano także liczbę uczestników synodu i szeroko omówiono nieobecność hierarchów z Państwa Środka. W dalszej części wymieniono problemy jakie podjęli ojcowie synodalni. Jako pierwsze przedstawione było zagadnienie analfabetyzmu, biedy oraz wyzysku o czym mówił kardynał Paul Shan Kuo-hsi. Następnie cytowano wypowiedzi biskupa Bastera oraz arcybiskupa Shimamoto, którzy podjęli głos o potrzebie budowania autentycznego Kościoła azjatyckiego. W dwóch kolejnych numerach „Niedzieli” zostały podane kolejne wystapienia odnoszące się do kwestii dyskryminacji kobiet i ich instrumentalnego traktowania. Obok głosu ojca Remigiusa, na uwagę zasługuje cytat siostry Filomeny Hiroty z Japonii. Na łamach „Niedzieli” została poruszona również kwestia niestabilnej sytuacji w Jerozolimie i na Bliskim Wschodzie, o czym mówił arcybiskup Bustors, kardynał Sfeir oraz arcybiskup Sabbah. Tygodnik, jako jedyny poświęcił miejsce na zamieszczenie głosów odnoszących się do wspomnianych wcześniej terenów. Inaczej wyglądało ukazanie sytuacji Kościoła w Chinach w dwóch wypowiedziach biskupa Tong Hona i biskupa Zu- 
Kiuna, gdyż w większości pism mogliśmy odnaleźć wzmianki o Państwie Środka. Sytuacje innych krajów o których mogliśmy przeczytać w trakcie lektury „Niedzieli” to: Korea, o której mówił kardynał Kim Sou-hwan oraz Mongolia o której opowiadał ojciec Padilla.

Wśród problemów kontynentu azjatyckiego wymieniono także potrzebę dialogu. Zaakcentował to w szczególności biskup Marayati, który zaapelował do Watykanu o przygotowanie dokumentu dotyczącego stosunków między katolikami a muzułmanami. Inną kwestię podjął biskup Claver, gdyż mówił on o potrzebie rzeczywistej inkulturacji.

W „Niedzieli”, podobnie jak w „Gościu Niedzielnym”, zabrakło do pełnego ukazania całego przebiegu zgromadzenia informacji odnoszącej się do homilii na zakończenie obrad. Przedstawiono jedynie główne punkty orędzia ojców synodalnych jakie skierowali oni do wiernych. W czasopiśmie zabrakło także ukazania fazy przygotowawczej synodu oraz artykułu ukazującego obecną sytuację Kościoła w Azji.

W „Przeglądzie Powszechnym”, podobnie jak w poprzednich tygodnikach, pierwsza wzmianka o synodzie ukazała się w dwa tygodnie po jego rozpoczęciu. Zawierała ona skrótowy zarys przesłania homilii wygłoszonej podczas uroczystej inauguracji. Dla czytelników chcących poznać przebieg zgromadzenia kolejne numery przyniosły rozczarowanie, gdyż nie zamieszczono w nich żadnych informacji o dalszym toku prac ojców synodalnych.

Nasze rozważania odnoszące się do czasopism ogólno kościelnych zamknie „Przegląd Powszechny”, w którym zamieszczono informacje o synodzie niemalże dwa miesiące po zakończeniu obrad. W artykule Marka Blazzy ukazano zapowiedź zwołania zgromadzenia oraz omówiono krótko aktualną sytuację Kościoła w Azji. Wspomniano także o nieobecności chińskich biskupów. Absencja delegatów z Państwa Środka została szczególnie uwypuklona gdyż podobną ilość tekstu poświecono na ukazanie zagadnień poruszanych na synodzie.

Pierwsza grupa tematów ukazana w artykule odnosiła się do jedności Kościoła i wiernego przyjmowania nauczania papieskiego o czym mówili kardynałowie: Angelo Sodano oraz Joseph Ratzinger. Kolejne głosy odnosiły się z kolei do potrzeby głoszenia Jezusa Chrystusa jako jedynego Zbawiciela oraz do koniecznej odwagi w potwierdzaniu wyjątkowości zbawczej roli Pana na tle innych religii, co zaakcentowali biskupi: Baum oraz Patabendige. Ponadto autor przedstawił problem poruszany wielokrotnie na synodzie, odnoszący się do inkulturacji. Niestety nie poparł tego żadnym cytatem, co uczynił chociażby ukazując zagadnienie kultu przodków praktykowany w wielu azjatyckich krajach, podpierając się na wypowiedzi kardynała Tong Hona. Na zakończenie ukazana została sytuacja Kościoła w Korei Północnej w wypowiedzi kardynała Kim Sou-hwana oraz zakreślono obraz społeczności wiernych w Mongolii, podpierając się głosem przełożonego misji sui iuris w Ułan Bator, ojca Padilli. 
Nie trudno zauważyć, że w tak ukazanych problemach zabrakło miejsca na poruszenie kwestii z zakresu życia społecznego czy ekonomicznego. W artykule nie otrzymaliśmy również informacji odnoszącej się do homilii na rozpoczęcie oraz zakończenie obrad. Gdyby umieszczono w tekście brakujące elementy, stałby się wartościowym opracowaniem zgromadzenia azjatyckich hierarchów.

Synod dla Azji został zaakcentowany nie tylko na łamach ogólnopolskich czasopism katolickich. Wydarzenie to odbiło się echem również w pismach posiadających charakter ściśle misyjny. I tak „Misyjne Drogi” umieściły pierwszą wzmiankę o zgromadzeniu w dwa miesiące po zakończeniu obrad. W krótkiej adnotacji przekazano główną myśl homilii wygłoszonej podczas uroczystej inauguracji oraz podano liczbę uczestników.

Kolejny numer, wrześniowo-październikowy, w całości został poświęcony tematyce synodu, co było fenomenem w obliczu pozostałych tytułów. Zaowocowało to także głębszym i szerszym podejściem do tematu. Artykuł ojca Madeja mówił o wielkim znaczeniu zgromadzenia dla kontynentu. Zaakcentował przy tym poczucie wspólnoty, podkreślając przy tym fakt wprowadzenia w liturgię rozpoczynającą obrady, elementów zaczerpniętych z rodzimej tradycji i kultury. W piśmie zamieszczono także wywiad z arcybiskupem Phan Min Manem, który ukazał czytelnikom sytuację panującą w Kościele sajgońskim. Podobnych rozmów nie odnaleźliśmy w żadnych innych pismach katolickich.

„Misyjne Drogi” ukazały także aktualną sytuację Kościoła w Azji. Przedstawiono również główne wyzwania w obliczu których stoi tamtejszy Kościół. Czytelnicy mogli też zapoznać się z przebiegiem zgromadzenia oraz przygotowaniami jakie go poprzedziły. Wymieniono liczbę uczestników wyszczególniając przy tym Polaków biorących udział w obradach. Fakt ten zasługuje na uwagę, gdyż jedynie w tym miejscu wyróżniono obecność Polaków. Na łamach pisma zawarto krótką adnotację odnoszącą się do absencji biskupów z Chin, po czym skrótowo zarysowano przebieg obrad pomijając przy tym poruszaną problematykę, co stanowiło słaby punkt owego numeru. Z kolei orędzie skierowane do Ludu Bożego zostało bardzo szeroko omówione, omijając przy tym homilie na zakończenie obrad.

W czasopiśmie zamieszczono unikatową relację uczestnika synodu, ojca Cagnasso, który mówił o potrzebie re-ewangelizacji terenów byłego Związku Radzieckiego. Zakonnik podkreślił poczucie wspólnoty i ubogacenia jakie towarzyszyły uczestnikom.

W naszych rozważaniach nie mogło zabraknąć miejsca na „Misje Dzisiaj” gdzie w tekście Jana Jarco ukazano „Propositiones” złożone na ręce Ojca Świętego, które wykorzystane zostanie do utworzenia dokumentu posynodalnego „Ecclesia in Asia”. Omówiono również orędzie wygłoszone na zakończenie obrad. Przekrojowo podano wybrane problemy jakie zostały poruszone. Nie zamieszczono tu żadnych informacji na temat dokumentów przygotowawczych czy cho- 
ciażby homilii na rozpoczęcie obrad. Tekst stanowiłby dobre przekrojowe opracowanie tematu gdyby został uzupełniony o brakujące informacje.

Kolejnym pismem misyjnym poddanym pod refleksję jest miesięcznik „Idźcie na cały świat". W jednym z artykułów możemy dopatrzeć się przedpola w ukazaniu synodu dla Azji, gdyż został on poświęcony kongresom Zgromadzenia Konferencji Episkopatu Azji. Szóste zgromadzenie hierarchów odbywało się w stolicy Filipin - Manili, podczas którego papież wezwał do odkrywania autentycznego Kościoła azjatyckiego oraz zaapelował do biskupów kontynentu o pomoc w przygotowaniach do synodu.

W piśmie zamieszczono tekst Urszuli Madej, relacjonującej wydarzenie synodu. Autorka pominęła myśl dotyczącą homilii na rozpoczęcie obrad, ale nie opuściła adnotacji o liczbie uczestników, zaznaczając nieobecność hierarchów z Państwa Środka. Znaczą część artykułu poświęcono na ukazanie problematyki jaka dominowała podczas obrad. Podkreślono potrzebę podjęcia procesu inkulturacji oraz adaptacji kultu przodków, praktykowanego w wielu krajach. Autorka zaakcentowała również podziały jakie występują między katolikami żyjącymi w Chinach oraz ukazała trudną sytuację zrodzoną na terenie Bliskiego Wschodu. W artykule nie zabrakło miejsca na podkreślenie trudnej sytuacji kobiet i ich niskiej pozycji społecznej. Wymieniono problem dyskryminacji dziewcząt oraz nierówne płace będące palącymi kwestiami wymagającymi rozwiązania. Jak widzimy w tekście wymieniono jedynie wybrane problemy, co rzutuje na niepełny obraz tematyki poruszanej podczas obrad. Artykuł zakończono krótkim akcentem skoncentrowanym na głównej myśli homilii wygłoszonej podczas Liturgii na zakończenie obrad. Ponownie zwrócono uwagę na nieobecność biskupów z Państwa Środka oraz wyrażono nadzieję papieża na otwarcie się Kościoła chińskiego na Kościół powszechny.

W tekście zabrakło informacji odnoszących się do orędzia jakie wystosowali ojcowie synodalni do Ludu Bożego. Czytelnik nie zapoznał się podczas lektury artykułu z fazami jakie poprzedzały samo zgromadzenie azjatyckich biskupów. Brakowało w piśmie ukazania zapowiedzi zwołania specjalnych synodów kontynentalnych oraz informacji odnoszących się do „Lineamenta” oraz dokumentu roboczego „Instrumentum Laboris”.

$\mathrm{Na}$ łamach „Misjonarza” czytelnik mógł zapoznać się z bardzo fragmentarycznym przedstawieniem synodu dla Azji, nie ukazującym nawet zarysu obrad. Wspomniano jedynie o nieobecności chińskich biskupów, którzy uczestniczyli w zgromadzeniu za pomocą faksu oraz zaakcentowano wypowiedz biskupa Tong Hona, odnoszącą się do potrojenia się liczby wiernych w Państwie Środka. W tym samym numerze zamieszczono także felieton Henryka Jerzmańskiego, mówiący o różnorodności jaka obecna jest na kontynencie azjatyckim. Należy także dodać, że informacje odnoszące się do wydarzeń poprzedzających synod ograniczyły się do wzmianki na temat spotkania azjatyckich hierarchów na forum, które poświęcono 
analizie gospodarki regionu. Biskupi podjęli krytykę negatywnych zjawisk, takich jak korupcja, nepotyzm czy złe zarządzanie sektorem prywatnym i publicznym.

Felieton odnoszący się do wielkiej azjatyckiej mozaiki, który został zamieszczony w piśmie mógł stanowić dobre przedpole do ukazania problematyki jaką poruszyli ojcowie synodalni, jednak tak się nie stało. W czasopiśmie zabrakło także artykułu w którym moglibyśmy przeczytać relację ze specjalnego zgromadzenia azjatyckich hierarchów. Gdyby zamieszczono chociaż jeden tekst omawiający synod moglibyśmy zrozumieć brak informacji o nim w bieżących wydarzeniach. Należy wspomnieć, że w „Misjonarzu” znalazło się miejsce na przedstawienie i dość szczegółowe opracowanie synodu dla Oceanii.

Podobna sytuacja ujawniła się na łamach „Nurtu SVD”, kwartalnika poświęconego tematyce misjologicznej i religioznawczej. W piśmie nie zamieszczono żadnego artykułu poruszającego temat zgromadzenia azjatyckich biskupów w Watykanie, mimo iż wcześniej pojawiły się teksty omawiające synody dla Ameryki oraz Afryki. Pominięcie i brak opracowania obrad hierarchów z Azji stanowi niewattpliwie słaby punkt czasopisma, jednak ogromnym walorem stało się tłumaczenie oficjalnej odpowiedzi biskupów japońskich na „Lineamenta” jakie zawarte zostało na łamach „Nurtu SVD”. Stanowi to niezwykły okaz, gdyż jedynie w tym miejscu mogliśmy zapoznać się z polską wersją wspomnianego dokumentu, która niosła ze sobą ważne uwagi metodologiczne i tematyczne dla dalszych prac. Ponadto umieszczono tekst wprowadzający, gdzie wyjaśniono i omówiono przygotowania do stworzenia odpowiedzi na pytania które napłynęły z Watykanu.

Warto zauważyć także, że niektóre czasopisma misyjne całkowicie pominęły w swoich wydaniach informację odnoszące się do zgromadzenia azjatyckich hierarchów. W „Misjach Salezjańskich” nie ma żadnej wzmianki na temat synodu jaki był poświęcony Azji. Nie znajdujemy nawet krótkich wzmianek w kalendarium zamieszczanym w czasopiśmie, choć jest to miejsce w którym odnotowywane są bieżące wydarzenia jakie mają miejsce w Kościele powszechnym.

Na łamach czasopisma „Posyłam Was” oraz „Horyzontów Misyjnych” czytelnik także nie mógł zapoznać się z informacją mówiącą o specjalnym zgromadzeniu azjatyckich hierarchów. Nie zawarto informacji o tym wydarzeniu nawet w krótkich adnotacjach.

Powyżej ukazaliśmy jak zostało ukazane Specjalne Zgromadzenie Biskupów dla Azji na łamach polskiej prasy katolickiej. W naszej pracy opieraliśmy się na artykułach zaczerpniętych z najważniejszych czasopism mających największy wpływ na świadomość nie tylko religijną ale i misyjną chrześcijan w Polsce.

W wyniku analizy mogliśmy zauważyć różne podejścia w ukazaniu synodu. Niektóre czasopisma, takie jak „L'Osservatore Romano”, „Gość Niedzielny”, „Niedziela”, „Biuletyn KAI”, „Przewodnik Powszechny” „Idźcie na cały świat” czy „Misyjne Drogi”, starały się ukazać całościowo przebieg synodu. Natomiast 
„Przewodnik Katolicki”, „Nurt SVD” czy „Misjonarz” ograniczyły się w swoim przekazie jedynie do wybranych zagadnień, niejednokrotnie potraktowanych skrótowo i powierzchownie. Jednak zebranie treści zawartych w artykułach pozwoliło na całościowe przedstawienie przygotowań jakie podjęto przed rozpoczęciem zgromadzenia oraz samo rozpoczęcie, przebieg i zakończenie obrad. Ukazano także problematykę jaka poruszona została podczas obrad na auli synodalnej. Analiza wielu źródeł pozwoliła na pełniejsze i głębsze ukazanie tematu. Autorzy podejmujący wątek zgromadzenia azjatyckich hierarchów ukazywali rozmaite aspekty owego wydarzenia, jedni dbali o całościowe przedstawienie synodu, inni poprzestawali jedynie na skrótowych i niepełnych informacjach. Zauważyliśmy także, że niektóre czasopisma całkowicie pominęły temat zgromadzenia azjatyckich biskupów.

Polskie wydanie „L'Osservatore Romano” przedstawiło na swoich łamach bardzo dobry materiał źródłowy. Zamieszczając teksty homilii papieża oraz poszczególne wypowiedzi ojców synodalnych odnaleźliśmy w piśmie znakomitą bazę do opracowania przebiegu oraz problematyki poruszanej podczas obrad hierarchów. Jednak w polskim wydaniu „L'Osservatore Romano” nie mogliśmy odnaleźć artykułów omawiających kontekst oraz rzeczywistość w jakiej żyją wierni na kontynencie azjatyckim. Zostało to z kolei uzupełnione podczas lektury „Biuletynu KAI”, gdzie spotkaliśmy się z felietonami ukazującymi zarys sytuacji panującej na przykład w Chinach czy Wietnamie, pominięto jednak inne państwa. Czytelnik mógł śledzić postępy prac oraz poznać główne problemy jakie poruszali hierarchowie na bieżąco. W „Biuletynie KAI” raz w polskim wydaniu „L'Osservatore Romano” zapoznaliśmy się także z unikatowymi informacjami odnoszącymi się do ceremonii rozpoczęcia oraz zakończenia obrad.

Ogólnopolskie czasopisma katolickie jakie zostały omówione w powyższej pracy ukazywały wydarzenia z azjatyckiego synodu na bieżąco. Jednak podawane informacje były umieszczane $\mathrm{w}$ krótkich działach podających skróty wydarzeń, dlatego adnotacje odnoszące się do zgromadzenia ograniczane były jedynie do podania głównych myśli jakie pojawiły się podczas trwania obrad. W omawianych tygodnikach: „Gościu Niedzielnym”, „Niedzieli” i „Przewodniku Katolickim” mogliśmy zapoznać się jedynie $\mathrm{z}$ wyselekcjowanymi treściami. W żadnym $\mathrm{z}$ wymienionych tytułów nie odnaleźliśmy opracowania prac ojców synodalnych, nie mogliśmy także zapoznać się z obecną sytuacją jaka panuje w Kościele azjatyckim. Inne podejście ukazano na łamach „Przeglądu Powszechnego”, gdzie w odrębnym tekście ukazano przygotowania jakie poprzedziły synod oraz przedstawiono uwarunkowania w których żyją wierni na owym kontynencie. Autor omówił także problemy jakie poruszone były na obradach. Ograniczono się jednak tylko do zagadnień religijnych, pomijając tym samym kwestie z zakresu życia ekonomicznego, społecznego i politycznego. Gdyby uzupełniono artykuł o brakujące elementy stanowiłby on niewątpliwie wartościowe opracowanie. 
Wybrane czasopisma misyjne $\mathrm{w}$ różnym stopniu przedstawiały wydarzenie synodu. „Misjonarz” zawarł tylko adnotację o rozpoczęciu obrad oraz krótki artykuł odnoszący się do sytuacji Kościoła w Azji. Z kolei „Misyjne Drogi” jako jedyne, cały numer poświęciły na omówienie synodu, gdzie znaleźliśmy również wywiad z arcybiskupem Phan Min Man, opowiadającego o sytuacji Kościoła sajgońskiego. Wszystkie pisma misyjne podawały informację o zgromadzeniu azjatyckich biskupów z opóźnieniem, co wynika z częstotliwości wydawania owych tytułów, co nie obniża wartości owych treści, ale nie było możliwym śledzenie spraw na bieżąco. Na uwagę zasługuje tłumaczenie oficjalnej odpowiedzi biskupów japońskich na „Lineamenta”, jakie umieszczone zostało na łamach „Nurtu SVD”. Jednak w piśmie nie zamieszczono żadnego artykułu, który poruszałby temat samego zgromadzenia azjatyckich hierarchów. Dziwi ten fakt, zwłaszcza gdy, wcześniej umieszczone były teksty omawiające synod dla Afryki i Ameryki. Z kolei „Misje Salezjańskie”, „Posyłam Was” oraz „Horyzonty Misyjne" w ogóle nie zamieściły na swoich łamach informacji odnoszących się do odbywającego się w Watykanie specjalnego zgromadzenia azjatyckich hierarchów. W świetle owych trzech tytułów wynika, iż polscy czytelnicy byli mało zainteresowani Azją i związanymi z nią wydarzeniami.

Nie można było odnaleźć w polskiej prasie katolickiej tekstu lub czasopisma, który by w sposób idealny ukazał Specjalne Zgromadzenie Biskupów dla Azji. Możliwe, że wynikało to z braku lepszych źródeł informacji i dlatego redakcje nie miały dokładniejszych materiałów. Jednak analiza wszystkich artykułów i pozycji pozwoliła na skondensowanie i uzupełnienie brakujących informacji, co zaowocowało możliwością całościowego przedstawienia synodu.

\section{SUMMARY}

New challenges for the Church in Asia became the motive for calling by John Paul II the Synod for Asia. It took place in 1998 in Rome (19 $9^{\text {th }}$ of April $-14^{\text {th }}$ of May). The article traced how this synod was portrayed in the Polish Roman Catholic press. The author analyzed relations on the subject of the synod which appeared in the Polish Catholic press. At first she presented what was written in the Polish version of "L'Osservatore Romano" and in the "Bulletin KAI". This information was compared with the data which appeared in most important Polish Catholic weekly press and in the Polish missionary magazines.

Key words:

Asia - Church, Lineamenta, Instrumentum Laboris, Synod for Asia

Słowa klucze:

Azja-Kościół, Lineamenta, Instrumentum Laboris, Synod dla Azji 